\title{
L-Arginine-Incorporated Cement Mortar as Sustainable Artificial Reefs
}

\author{
Hyun-Min Yang ${ }^{1,2}$, Nosang V. Myung ${ }^{1}$, Han-Seung Lee ${ }^{3, *}$ and Jitendra Kumar Singh ${ }^{2, *(1)}$ \\ 1 Department of Chemical and Environmental Engineering, University of California-Riverside, Riverside, \\ CA 92521, USA; yhm04@hanyang.ac.kr (H.-M.Y.); myung@engr.ucr.edu (N.V.M.) \\ 2 Innovative Durable Building and Infrastructure Research Center, Department of Architectural Engineering, \\ Hanyang University, 1271 Sa-3-dong, Sangnok-gu, Ansan 15588, Korea \\ 3 Department of Architectural Engineering, Hanyang University, 1271 Sa 3-dong, Sangnok-gu, \\ Ansan 15588, Korea \\ * Correspondence: ercleehs@hanyang.ac.kr (H.-S.L.); jk200386@hanyang.ac.kr (J.K.S.)
}

Received: 8 June 2020; Accepted: 4 August 2020; Published: 6 August 2020

\begin{abstract}
L-arginine is one of the amino acids found in plant seeds. In the present study, various amounts (i.e., 3\%, 5\%, 10\%) of L-arginine were added to cement mortar to investigate the compressive strength, workability, leaching behavior, and $\mathrm{pH}$ change in distilled and natural seawater, as well as dissolved nitrogen and growth of chlorophyll-a (Chl-a) by immersion in natural seawater. The compressive strength of the cement mortar is decreased with increase in L-arginine content owing to the high flow/slump and air content. A concentration of $10 \%$ L-arginine significantly promoted the growth of Chl-a on the cement mortar for up to 56 days of immersion in natural seawater. This is due to the availability of high dissolved nitrogen and $\mathrm{pH}$ inside the pores. This study recommends the use of L-arginine in artificial reef structures where marine ecosystems can be maintained.
\end{abstract}

Keywords: L-arginine; cement mortar; artificial reef; chlorophyll-a; compressive strength; $\mathrm{pH}$

\section{Introduction}

Coastal ecosystems must be stabilized in underwater environments where marine algae, fish, and shellfish are found. Unfortunately, construction of artificial marine structures (e.g., artificial reef, seawall, tide embankment, tetrapod) causes extensive damage to the marine ecosystem [1]. They not only cause the loss of marine habitats and habitat fragmentation, but also restrict biodiversity more than natural rocks [2-6]. Artificial marine structures, which were constructed similarly to conventional structures, lead to maintenance of the alkalinity of concrete owing to the attached organism [7]. Moreover, freshly installed normal concrete may leach $\mathrm{KOH}, \mathrm{NaOH}$, and $\mathrm{Ca}(\mathrm{OH})_{2}$ ) into the sea, which inhibit the growth of marine life and decrease the mechanical properties of the concrete [8]. In addition, the pozzolanic materials can maintain the surface $\mathrm{pH}$, mechanical properties $[9,10]$, and chemical stability of the concretes.

The concrete structures installed in mountainous terrain and river water are free from dissolved ions. Therefore, this water is aggressive for the health of immersed concrete where the hydration products of concrete, such as Ettringite and calcium silicate hydrate (C-H-S), are leached out from the pore system and transported away by diffusion or water flow [11]. Once the hydration products leach out, then ultimately, the porosity and permeability of the concrete would increase, resulting in a decrease in compressive strength. However, the leaching may influence the permeability, amount of calcium-i.e., $\mathrm{Ca}(\mathrm{OH})_{2}$ - and $\mathrm{CO}_{2}$ content in the water, and hardness of the water. If all these are high, then leaching would be high. The leaching of pore water can be reduced by adding aluminum ferrite [11] and making dense concrete. Ekström (2001) has mentioned that pure water, which has 
the ability to dissolve the $\mathrm{Ca}(\mathrm{OH})_{2}$, percolating into the concrete specimens results in leaching by diffusion and convection [11]. This depends on the water/cement ratio and curing conditions. A high water/cement ratio encourages one to make the concrete more porous, resulting in higher water permeability. However, incorporation of nano silica particles reduces the porosity, transforming portlandite into C-S-H gel through a pozzolanic reaction and increasing the average chain length of the silicate, resulting in durable concrete that reduces the leaching of calcium ions [12]. The addition of nano silica induces the pozzolanic reaction, which transforms the more susceptible $\mathrm{Ca}(\mathrm{OH})_{2}$ into C-S-H gel. Therefore, leaching of $\mathrm{Ca}(\mathrm{OH})_{2}$ is reduced.

The diffusion of $\mathrm{Ca}(\mathrm{OH})_{2}$ can be reduced using additives such as wet biofilm, freeze-dried biofilm powder, and bacterial suspensions, which can prevent ingress of water into the concrete [13]. The bacteria can improve the durability of the concrete in a sulfate environment, which is attributed to the increase of the bulk density and lowering of the voids [14]. Sporosarcina pasteurii [15] and Bacillus megaterium [16] bacteria precipitate into the cement mortar, resulting in improvement of compressive strength.

L-arginine is one of the naturally existing amino acids that is present in plant seeds [17-20]. Moreover, L-arginine can act as an inhibitor to mitigate the corrosion of steel [21]. Gowri et al. (2014) studied the synergistic effect of L-arginine with $\mathrm{Zn}^{2+}$ to enhance the corrosion resistance properties of steel exposed in seawater [22]. They found that $250 \mathrm{ppm}$ L-arginine with $25 \mathrm{ppm} \mathrm{Zn}^{2+}$ showed 91\% inhibition efficiency. This study revealed that L-arginine can be used as an inhibitor for the protection of embedded steel rebar in concrete.

There have been many studies on leaching of inorganic elements from the concrete into water [23-26]. However, there are no studies on the leaching behavior of L-arginine-containing concrete in marine environments. Moreover, the effect of L-arginine on durability of the cement mortar has not yet been studied for application in an artificial reef.

In this manuscript, systematic studies were conducted to investigate the effect of L-arginine on various materials and chemical properties of cement mortar, including the compressive strength, workability, leaching behavior, and $\mathrm{pH}$ change in distilled and natural sea water, as well as dissolved nitrogen and growth of chlorophyll-a (Chl-a) by immersing into an actual sea for an artificial reef.

\section{Materials and Methods}

\subsection{Materials}

L-arginine ( $\geq 99.00 \%)$ was purchased from Sigma-Aldrich, and the properties are shown in Table 1 . The cement mortar was prepared using standard Portland cement [27]. The specific gravity and specific surface area of the cement were $3150 \mathrm{~kg} / \mathrm{m}^{3}$ and $395 \mathrm{~m}^{2} / \mathrm{kg}$, respectively. The chemical composition of cement is shown in Table 2. Natural sand was used as the fine aggregate according to ASTM C33 [28]. The size, apparent density, and water absorption of the fine aggregate were less than $4.75 \mathrm{~mm}$, $2461 \mathrm{~kg} / \mathrm{m}^{3}$, and $2.6 \%$, respectively.

Table 1. Properties of L-arginine.

\begin{tabular}{cc}
\hline Division & Properties \\
\hline Formula & $\mathrm{C}_{6} \mathrm{H}_{14} \mathrm{~N}_{4} \mathrm{O}_{2}$ \\
Molecular weight & $174.20 \mathrm{~g} / \mathrm{mol}$ \\
$\mathrm{pH}$ & 12.0 at $25^{\circ} \mathrm{C}$ \\
Melting point & $22{ }^{\circ} \mathrm{C}$ \\
Water solubility & $87.1 \mathrm{~g} / \mathrm{L}$ at $20{ }^{\circ} \mathrm{C}-$ completely soluble \\
\hline
\end{tabular}


Table 2. Chemical composition of cement.

\begin{tabular}{cc}
\hline Chemical Composition & Cement (wt.\%) \\
\hline $\mathrm{SiO}_{2}$ & 23.20 \\
$\mathrm{Al}_{2} \mathrm{O}_{3}$ & 5.03 \\
$\mathrm{Fe}_{2} \mathrm{O}_{3}$ & 2.92 \\
$\mathrm{CaO}$ & 62.40 \\
$\mathrm{MgO}$ & 2.07 \\
$\mathrm{SO}$ & 2.34 \\
$\mathrm{~K}_{2} \mathrm{O}$ & 0.59 \\
$\mathrm{Na}_{2} \mathrm{O}$ & 0.26 \\
Loss of ignition & 1.19 \\
\hline
\end{tabular}

\subsection{Specimen Preparation}

Mortar specimens were prepared using a 0.5 water/binder (W/B) ratio with different L-arginine contents (i.e., $0 \%, 3 \%, 5 \%$, and $10 \%$ ). The details of the mixing proportions of mortar with different L-arginine replacement ratios are shown in Table 3. L-arginine acts as a binder in cement mortar. In order to evaluate the mechanical properties and environmental activity of L-arginine mortars, the specimens were subjected to curing at $20( \pm 2.5){ }^{\circ} \mathrm{C}$ and $60 \%( \pm 5 \%)$ relative humidity for $24 \mathrm{~h}$ thereafter they were demolded and cured in tap water as well as natural seawater at $20( \pm 2.5)^{\circ} \mathrm{C}$ for up to 56 days.

Table 3. Mortal mixture proportions.

\begin{tabular}{|c|c|c|c|c|c|}
\hline \multirow{2}{*}{$\mathbf{W} / \mathbf{B}$} & \multirow{2}{*}{ L-Arginine (\%) } & \multicolumn{4}{|c|}{ Mix Composition $\left(\mathrm{kg} / \mathrm{m}^{3}\right)$} \\
\hline & & Water & Cement & Sand & L-Arginine \\
\hline \multirow{4}{*}{0.5} & 0 & \multirow{4}{*}{255} & 510 & \multirow{4}{*}{1530} & 0 \\
\hline & 3 & & 494.7 & & 15.3 \\
\hline & 5 & & 484.5 & & 25.5 \\
\hline & 10 & & 459 & & 51 \\
\hline
\end{tabular}

\subsection{Test Methods}

\subsubsection{Flow/Slump Value and Air Content}

In order to evaluate the workability of mortar with L-arginine, a flow test was performed according to ASTM C1437 [29] and compared with ASTM C230 [30]. The same fresh cement mortars were measured three times, and the average value was reported. The evaluation of air content in the mortar with L-arginine was carried out by ASTM C185 [31].

\subsubsection{Compressive Strength}

The cement mortar with $50 \times 50 \times 50 \mathrm{~mm}$ dimensions was prepared for the compressive strength measurement. The cement mortar specimen was cured in tap water and seawater. The compressive strength of the cement mortar at $3,7,14,28$, and 56 days cured at $20( \pm 2){ }^{\circ} \mathrm{C}$ was measured according to ASTM C109 [32]. At each curing duration, three identical specimens were measured and the average value was taken as a result.

\subsubsection{Leaching Test for L-Arginine}

The cement mortar specimens with $50 \times 50 \times 50 \mathrm{~mm}$ dimensions were prepared to analyze the leaching behavior of L-arginine. The cement mortar was cured in a closed/dark chamber at $20{ }^{\circ} \mathrm{C}$ and $60 \%( \pm 5 \%)$ relative humidity for 28 days; thereafter, they were removed. The cured mortar was pulverized to less than $100 \mu \mathrm{m}$ and dispersed by taking $1 \mathrm{~g}$ each in 25, 50, 100, 300, 500, and $1000 \mathrm{~mL}$ distilled water and stirring for $1 \mathrm{~h}$. The obtained suspension was separated by glass fiber filter 
(GF/C, $1.2 \mu \mathrm{m})$; then, the L-arginine content of the liquid (solution) was analyzed by high-performance liquid chromatography (HPLC, Agilent 1100 High-Performance Liquid Chromatography, Waldbronn, Germany). In addition, the remaining part (residue or undissolved) of L-arginine on the filter paper was washed with acid-alkali solution (acetonitrile); thereafter, it was dissolved in 100, 300, and $500 \mathrm{~mL}$ of $0.1,0.5$, and $1 \mathrm{M} \mathrm{HCl}$ solution for $1 \mathrm{~h}$.

\subsection{4. $\mathrm{pH}$ Determination}

The $\mathrm{pH}$ (Thermo Scientific Orion, Waltham, Massachusetts, United State America) determination of L-arginine-containing cement mortar was carried out in distilled water and seawater with different immersion times at $20( \pm 2.5)^{\circ} \mathrm{C}$. The $\mathrm{pH}$ meter was directly dipped in the abovementioned water to measure the $\mathrm{pH}$ of the solution [33-35] at designated durations of immersion. The cylindrical cement mortar specimens of $\varnothing 100 \times 200 \mathrm{~mm}$ were directly immersed in a 5-L polypropylene plastic container with $300 \times 400 \mathrm{~mm}$ dimensions for determination of the solution $\mathrm{pH}$.

\subsubsection{Dissolved Nitrogen}

The amount of dissolved nitrogen in L-arginine-containing cement mortar was determined according to ASTM D8083 [36]. In this procedure, $100 \mathrm{~g}$ homogenized powder of each specimen $(0 \%, 3 \%, 5 \%$, and $10 \%$ L-arginine) was centrifuged in a 5 -L glass beaker by adding $1000 \mathrm{~mL}$ distilled water for $20 \mathrm{~min}$; then, it was filtered. It was measured for up to 56 days. The supernatant was recovered and stored in a polypropylene bottle. The total dissolved nitrogen was measured using a Shimadzu TOC-V analyzer (Shimadzu Corp., Kyoto, Japan). This experiment was performed with triplicate sets of specimens and the average values were reported.

\subsubsection{Evaluation of Chlorophyll-A Amount}

The amount of chlorophyll-a (Chl-a) in L-arginine-containing cement mortar specimens was evaluated by immersing them in a natural sea near the Sihwa tide embankment lake located at Ansan city, South Korea according to ASTM D3731 [37].

It was observed that after immersion of the cement mortar specimens in the sea, generally, Chl-a started to be attached or to float. The attached Chl-a was removed from the surface of the cement mortar immersed in the sea with distilled water using a sterilized semi-aromatic polyamide-based brush on a $5 \mathrm{~cm}^{2}$ surface area for different durations of immersion, as shown in Figure 1.

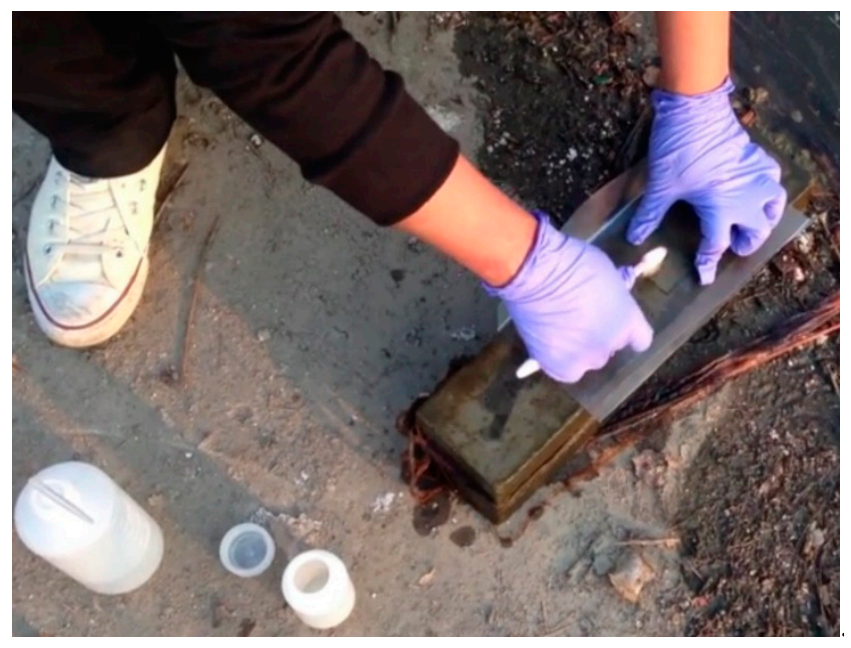

Figure 1. Removal of chlorophyll-a from the cement mortar specimen immersed in sea.

The collected Chl-a was stored in a non-light polypropylene bottle with $1 \mathrm{~mL}$ of magnesium carbonate suspension. The stored $\mathrm{Chl}$-a was filtered through the glass fiber filter (GF/C, $1.2 \mu \mathrm{m})$ using 
$15 \mathrm{KPa}$ or less pressure for $20 \mathrm{~min}$ within $24 \mathrm{~h}$ of storing. The residue and filter paper were ground and homogenized in $5 \mathrm{~mL}$ acetone solution (acetone: 90\%, distilled water: 10\%) for $3 \mathrm{~min}$. The ground specimen was placed in a centrifuge tube, sealed, and stored for $24 \mathrm{~h}$ in a light-free environment at $4{ }^{\circ} \mathrm{C}$. The specimen was then centrifuged for $20 \mathrm{~min}$ to prepare a supernatant. This sample was transferred to a $10 \mathrm{~mm}$ absorption cell. Acetone was considered as a control solution, and the optical density (OD) of the specimen using a Cary ${ }^{\circledR} 50$ UV-Vis Spectrophotometer (Varian Inc., Palo Alto, CA, USA) was measured at 664, 647, 630, and $750 \mathrm{~nm}$. The concentration of Chl-a on the mortar surface was calculated using the Jeffrey and Humphrey equation [38].

$$
\operatorname{Chl}-\mathrm{a}\left(\mu \mathrm{g} / \mathrm{cm}^{2}\right)=\frac{\left(11.64 X_{1}-2.16 X_{2}+0.01 X_{3}\right) \times V_{1}}{A}
$$

where $X_{1}$ is OD 664-OD 750, $X_{2}$ is OD 647-OD 750, and $X_{3}$ is OD 630-OD 750. $V_{1}$ is the volume of supernatant $(\mathrm{mL})$ and $A$ is the surface area of the cement mortar $\left(\mathrm{cm}^{2}\right)$.

\section{Results and Discussion}

\subsection{Properties of Cement Mortar with L-Arginine}

\subsubsection{Flow/Slump and Air Content of Fresh Cement Mortar}

The workability (flow/slump) and air content tests were performed with different amounts of L-arginine. Figure 2 shows the results of the flow/slump and air content of the L-arginine cement mortar. The workability of the mortar with L-arginine showed that the flow/slump value is increased as the amount of L-arginine in the cement mortar is increased owing to the higher dissolution [39]. It was observed that $3 \%, 5 \%$, and $10 \% \mathrm{~L}$-arginine-containing cement mortar exhibited increases in slump value of about $3.5 \%, 10 \%$, and $21 \%$, respectively, compared to without cement mortar L-arginine, i.e., $0 \%$. The air content also increased as the amount of L-arginine increased (Figure 2) owing to the characteristics of L-arginine, which include water absorption [40,41]. The increase in air content values of L-arginine-containing cement mortar is due to the increase in the interfacial effect between non-hydrated cement particles and L-arginine. L-arginine acts as an acid-base cationic surfactant where it reduces the surface tension and allows the formation of stable bubbles [42-45] on the surface of the cement and sand particles. Thus, flow and air content are increased with addition of L-arginine in cement mortar.

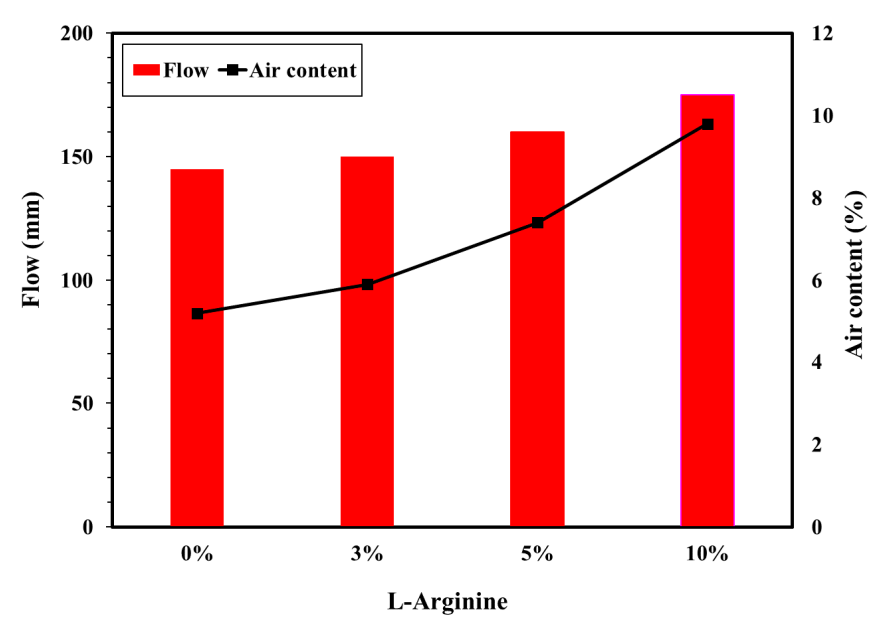

Figure 2. Flow and air content of cement mortar with different L-arginine replacement ratios. 


\subsubsection{Compressive Strength}

The compressive strength of L-arginine-containing cement mortar was measured by curing in tap water and seawater, and the results are shown in Figures 3 and 4, respectively. It is observed from these figures that the compressive strength of the cement mortar specimens is gradually increased with curing duration. The compressive strength of the specimens after 28 days of curing in tap water was found to be 28.6, 26.9, 24.6, and 22.9 MPa for $0 \%, 3 \%, 5 \%$, and $10 \%$ L-arginine replacement, respectively (Figure 3). The increase in compressive strength with curing duration could be attributed to the hydration reaction. The decrease in compressive strength of specimens (Figure 3) with increase in L-arginine replacement can be attributed to the higher flow/slump value and air content (Figure 2), which leads to the increase of the micro-cracks/defects inside of the cement mortar. If the air content is higher, the compressive strength of the specimen would be lower owing to the inward diffusion of water molecules. Thus, $10 \%$ L-arginine-containing cement mortar (Figure 3) shows the lowest compressive strength compared to the other specimens. Moreover, there is a possibility that the softening effect of cement mortar may occur upon loading for compression, and the preexisting micro-cracks propagate and form new one. Therefore, the load carrying capacity of the cement mortar decreases as the peak load of deformation increases in L-arginine-containing cement mortar [46,47].

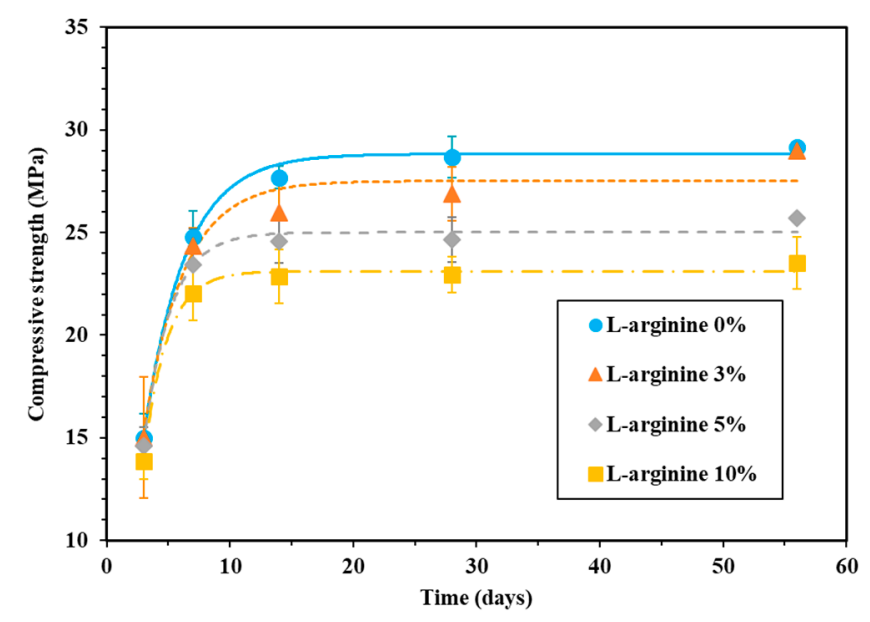

Figure 3. Compressive strength of mortar with L-arginine cured in tap water.

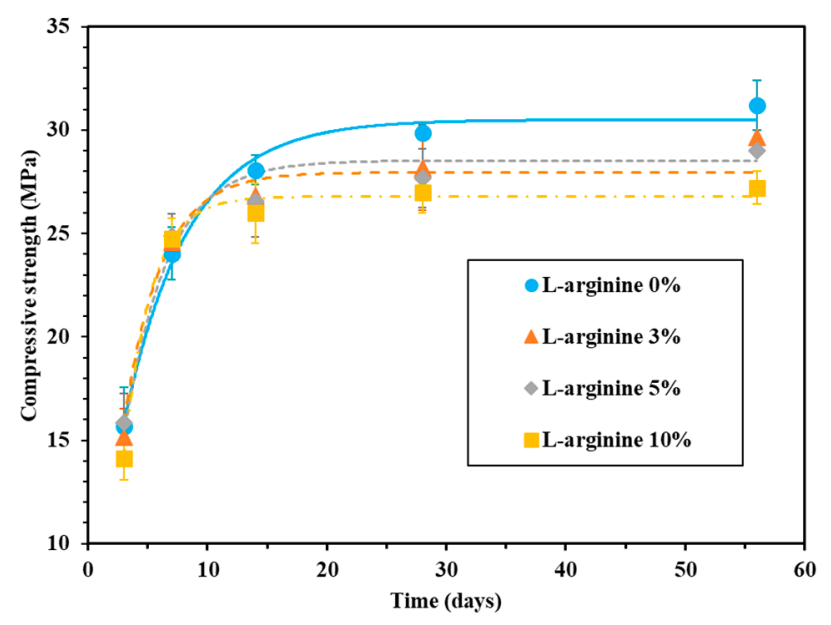

Figure 4. Compressive strength of mortar with L-arginine cured in seawater.

In the case of seawater curing, the compressive strength of $0 \%, 3 \%, 5 \%$, and $10 \%$ L-arginine-containing cement mortar after 28 days of curing was found to be 29.9, 28.2, 27.7, and $26.9 \mathrm{MPa}$, respectively (Figure 4). As the amount of L-arginine replacement increased, the compressive strength of 
the cement mortar decreased. The reduction in compressive strength of L-arginine-containing cement mortar is due to the higher content of entrained air during curing in seawater. The compressive strength of seawater-cured cement mortar was higher compared to tap water for all curing durations. This is attributed to the formation of Friedel's salt by the hydration products i.e., $\mathrm{Al}_{2} \mathrm{O}_{3}-\mathrm{Fe}_{2} \mathrm{O}_{3}$-mono (AFm) or -tri (AFt) [48]. Moreover, the $\mathrm{Cl}^{-}$ions from seawater can infiltrate during curing [49-51]. Thus, the filling ability of pores by Friedel's salt evidently improved the compressive strength of the cement mortar [47,52].

\subsection{L-Arginine Extraction from Hardened Cement Mortar}

\subsubsection{Extraction of L-Arginine in Distilled Water}

Figure 5 shows the recovery of L-arginine leached from $1 \mathrm{~g}$ of cement mortar in distilled water. From this figure, it can be seen that the recovery of L-arginine started to occur from $65 \%$ for $3 \%$ L-arginine-containing cement mortar in $25 \mathrm{~mL}$ distilled water. As the amount of L-arginine was increased up to $10 \%$, the recovery was found to be around $69 \%$ in $25 \mathrm{~mL}$ distilled water. In addition, when the volume of distilled water reached up to $500 \mathrm{~mL}$, the recovery was found to be $78 \%$ and $84 \%$ for 3\% and 10\% L-arginine-containing cement mortar, respectively. Moreover, it can be observed from Figure 5 that once the volume of distilled water is increased beyond $500 \mathrm{~mL}$, there is no significant recovery of L-arginine in any L-arginine-containing cement mortars. As a result, $500 \mathrm{~mL}$ of distilled water was sufficient to extract L-arginine. Moreover, when the volume of distilled water was same, i.e., $25,50,100,300,500$, and $1000 \mathrm{~mL}$ for a particular L-arginine-containing mortar, the recovery rate increased owing to the solubility of L-arginine in distilled water. Since L-arginine is soluble and mostly remained in the pore water, it could be extracted with distilled water. It is not possible to recover $100 \%$ L-arginine; therefore, another solution is required to recover it completely. Therefore, we used 100, 300 , and $500 \mathrm{~mL}$ of $0.1,0.5$, and $1 \mathrm{M} \mathrm{HCl}$ solution. In the subsequent paragraph, we will discuss the recovery of $\mathrm{L}$-arginine in $\mathrm{HCl}$ solution.

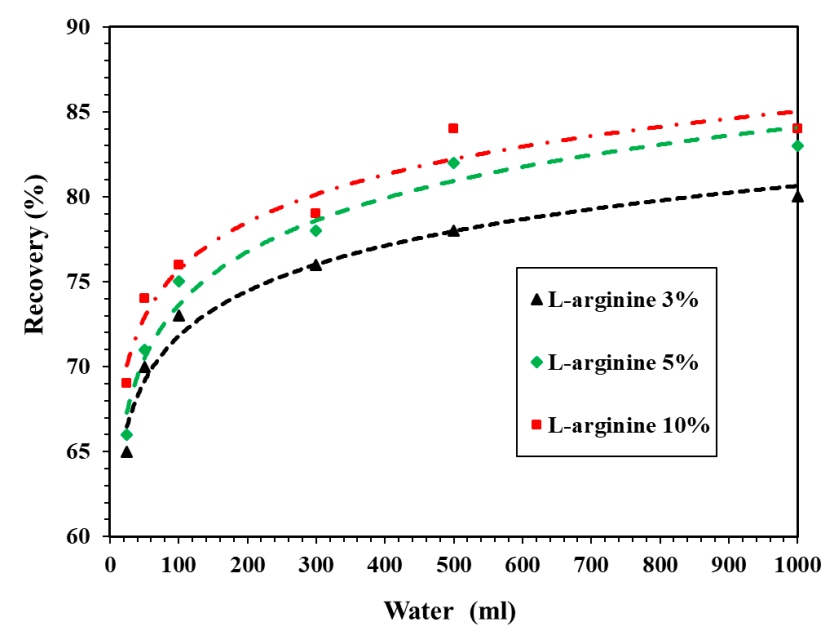

Figure 5. Recovery of L-arginine in distilled water.

\subsubsection{Recovery of Undissolved L-Arginine in $\mathrm{HCl}$}

The residue (remaining part of undissolved L-arginine-containing cement mortar in distilled water) can be dissolved in $0.1 \mathrm{M} \mathrm{HCl}$ solution. L-arginine can dissolve in distilled water, but owing to the cement and sand in cement mortar, some L-arginine was adsorbed on the surface and not dissolved in distilled water; therefore, $\mathrm{HCl}$ was used to dissolve the remaining $\mathrm{L}$-arginine. It was observed from Figure 5 that the recovery of L-arginine is optimum in $500 \mathrm{~mL}$ distilled water; thus, we selected only $500 \mathrm{~mL}$ of $0.1 \mathrm{M} \mathrm{HCl}$ solution to recover the remaining L-arginine from the residue. 
Figure $6 \mathrm{a}$ shows the recovery of L-arginine leached into the $0.1 \mathrm{M} \mathrm{HCl}$ solution. It can be seen in this figure that, as the volume of $0.1 \mathrm{M} \mathrm{HCl}$ solution increased, the recovery of L-arginine increased. The maximum recovery was found to be $8.27 \%$ by the $10 \%$ L-arginine-containing cement mortar specimen, followed by $5 \%$ and $3 \% \mathrm{~L}$-arginine around $8.15 \%$ and $8.05 \%$, respectively. Figure $6 \mathrm{~b}$ shows the recovery of $5 \% \mathrm{~L}$-arginine with respect to the concentration of $\mathrm{HCl}$ solution. It can be observed from Figure 6 a that $5 \%$ L-arginine exhibited the optimum amount of recovery. Thus, it was our prudent thought to consider only this specimen for the recovery of L-arginine with different concentrations of $\mathrm{HCl}$ solution. It can be observed from Figure $6 \mathrm{~b}$ that, as the concentration of $\mathrm{HCl}$ increased from 0.1 to $1 \mathrm{M}$, the recovery was almost constant. Therefore, from this result, it is suggested that the leaching of L-arginine into the mortar is found to be more sensitive to the volume of $\mathrm{HCl}$ solution rather than concentration.
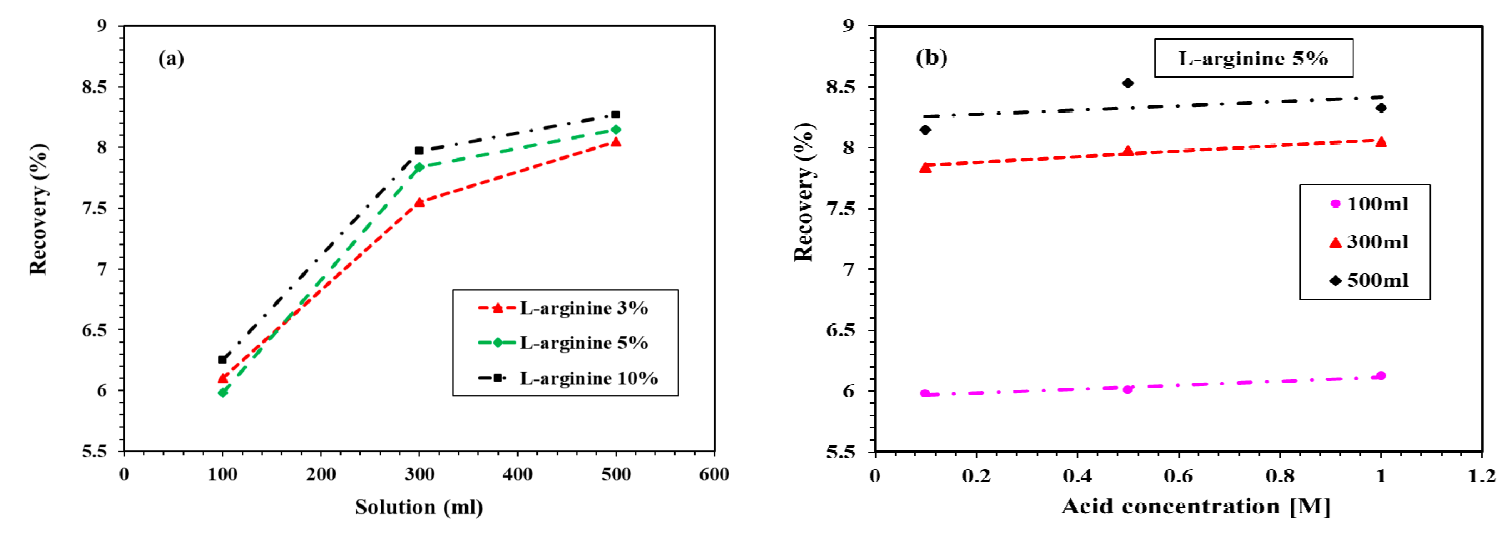

Figure 6. Recovery of L-arginine with (a) different amounts of L-arginine-containing cement mortar in $0.1 \mathrm{M} \mathrm{HCl}$ and (b) 5\% L-arginine with concentration and volume of $\mathrm{HCl}$ from the residue.

\subsection{Evaluation of the Impact of the Environmental Activity of L-Arginine-Containing Mortar}

\subsubsection{Change of $\mathrm{pH}$ Value According to the Type of Water Used to Immerse Cement Mortar with L-Arginine}

The changes in $\mathrm{pH}$ of the cement mortar immersed in distilled water and seawater are shown in Figure $7 \mathrm{a}, \mathrm{b}$, respectively. The $\mathrm{pH}$ of each data point is normally an average of three measurements. Figure 7a shows the change in $\mathrm{pH}$ of L-arginine-containing cement mortar immersed in distilled water according to duration. During immersion of L-arginine cement mortar in distilled water, the $\mathrm{pH}$ of the distilled water was measured, and it was found to be 7.3. It can be observed from Figure 7a that, as the amount of L-arginine-containing cement mortar is increased, the $\mathrm{pH}$ is increased. The $\mathrm{pH}$ value of each specimen initially increased for up to seven days; thereafter, it was marginally reduced. Initially, i.e., on day 0 , $\mathrm{L}$-arginine did not react with water; thus, it shows tap water $\mathrm{pH}$, but as the immersion time increased, L-arginine started to dissolve and $\mathrm{pH}$ was increased (Figure 7a). After seven days' immersion of $0 \%, 3 \%, 5 \%$, and $10 \% \mathrm{~L}$-arginine-containing cement mortar, the $\mathrm{pH}$ values of distilled water are found to be $12.13,12.55,12.71$, and 12.76, respectively. It is observed from Figure 7a that the $\mathrm{pH}$ was gradually reduced after seven days of immersion owing to several factors, such as carbonation from the external atmosphere, slow equilibrium, dilution from the excessive volume of water in the pores, and leaching of pore water, i.e., $\mathrm{KOH}, \mathrm{NaOH}$, and $\mathrm{Ca}(\mathrm{OH})_{2}$ [53].

Figure $7 \mathrm{~b}$ shows the change in $\mathrm{pH}$ of L-arginine-containing cement mortar immersed in seawater. It can be seen from this figure that the $\mathrm{pH}$ gradually increased for up to seven days, as similarly observed in tap water (Figure 7a), but after seven days of immersion, it decreased. The $\mathrm{pH}$ value of the seawater was 8.14. Therefore, initially, all specimens showed identical $\mathrm{pH}$, i.e., 8.14. For seven days of immersion, the $\mathrm{pH}$ of seawater was found to be $10.45,9.78,9.69$, and 9.36 for $0 \%, 3 \%, 5 \%$, and $10 \% \mathrm{~L}$-arginine-containing cement mortar, respectively. It can be seen from Figure $7 \mathrm{~b}$ that without L-arginine-containing cement mortar, i.e., $0 \%$ L-arginine, the cement mortar exhibited higher $\mathrm{pH}$ values compared to L-arginine-containing cement mortar. This is a contradictory result in the $\mathrm{pH}$ of 
seawater-immersed specimens compared to tap-water-immersed specimens. There is a probability that $\mathrm{Ca}(\mathrm{OH})_{2}$ can leach out from the pores of $0 \% \mathrm{~L}$-arginine cement mortar into seawater; thus, higher in $\mathrm{pH}$ is observed (Figure $\mathrm{7b}$ ). On the other hand, L-arginine-containing mortar attracts marine organisms, which attach to the surface of the cement mortar specimen. The marine organisms prevent the ingress of water molecules from the seawater and maintain the inside $\mathrm{pH}$ of the cement mortar. Moreover, there are fewer chances to diffuse the $\mathrm{Ca}(\mathrm{OH})_{2}$ from the cement mortar into the seawater; thus, it the seawater $\mathrm{pH}$ is shown. However, there were some bacteria present in seawater that catalyzed the hydrolysis of urea or amino acids into ammonia and caused the increase in $\mathrm{pH}$ up to seven days of immersion [13]. In the meantime, they also produce $\mathrm{CO}_{2}$ or carbonic acid, which induce calcite $\left(\mathrm{CaCO}_{3}\right)$ formation. Thus, reduction in $\mathrm{pH}$ was observed from 14 to 28 days (Figure $7 \mathrm{~b}$ ). There is another possibility that atmospheric $\mathrm{CO}_{2}$ can cause reduction in the $\mathrm{pH}$ of seawater after seven days of immersion for all specimens. This experiment was conducted in the absence of sunlight; thus, the microorganisms of seawater could not photosynthesize, resulting in higher amounts of $\mathrm{CO}_{2}$. Therefore, lower $\mathrm{pH}$ was observed compared to distilled water.

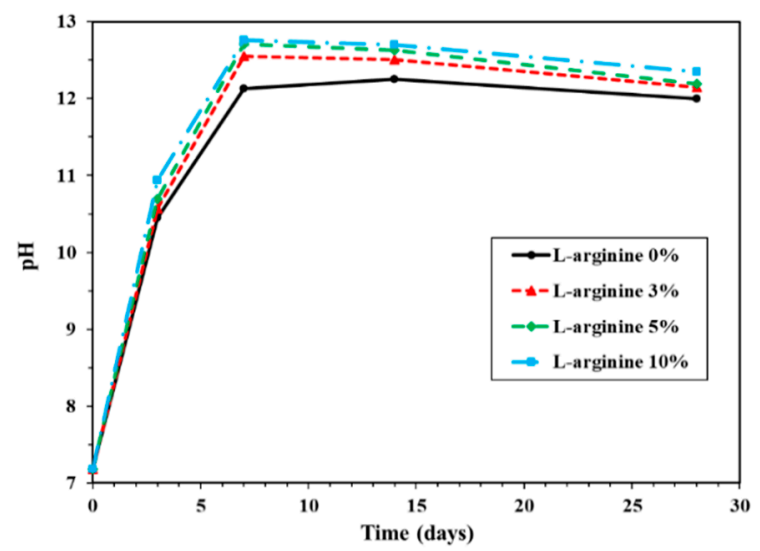

(a)

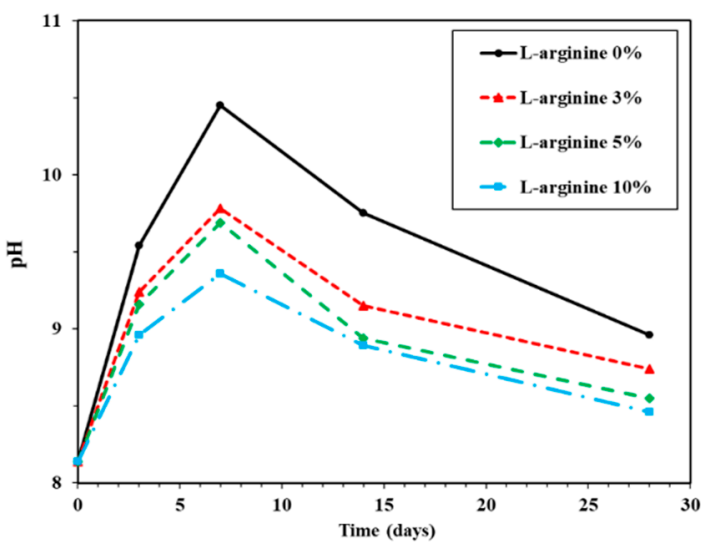

(b)

Figure 7. pH values of (a) distilled water and (b) seawater used to immerse test specimens.

3.3.2. Time Required to Change the Color of River Water after Immersion of L-Arginine-Containing Cement Mortar

Figure 8 shows the change in color of L-arginine-containing cement mortar immersed in seawater according to duration. It is believed that marine organisms can consume nutrients, e.g., nitrogen in the presence of $\mathrm{CO}_{2}$ and sunlight from the atmosphere by photosynthesis. Therefore, they float on the surface of water to obtain the nutrients from the air. It can be seen from Figure $8 \mathrm{a}, \mathrm{b}$ that initially, i.e., three days and seven days of immersion, there was no significant difference in the color of seawater for all concentrations of L-arginine-containing cement mortars. However, after seven days of immersion, change in the color of seawater was observed. Therefore, it is required to provide oxygen for survival of marine lives. We artificially provided air bubbles in the seawater to make oxygen available. Once the immersion duration was extended up to 14 days, the change in color of seawater from colorless to green (Figure 8c) with low amounts, i.e., $0 \%$ and $3 \%$, of L-arginine in cement mortar was observed owing to the lack of nitrogen (an essential element for growth of organisms), which cannot significantly diffuse from the pores of cement mortar. Thus, the chlorophyll-a (green color) floats in seawater to take nutrients (nitrogen) and light from the atmosphere. However, once the amount of L-arginine in the cement mortar was increased from $5 \%$ to $10 \%$ (high amount of nitrogen), after 14 days of immersion, there was no change in the color of seawater (Figure 8c), which can be attributed to the consumption of nutrients by chlorophyll-a in the water. 
(a)
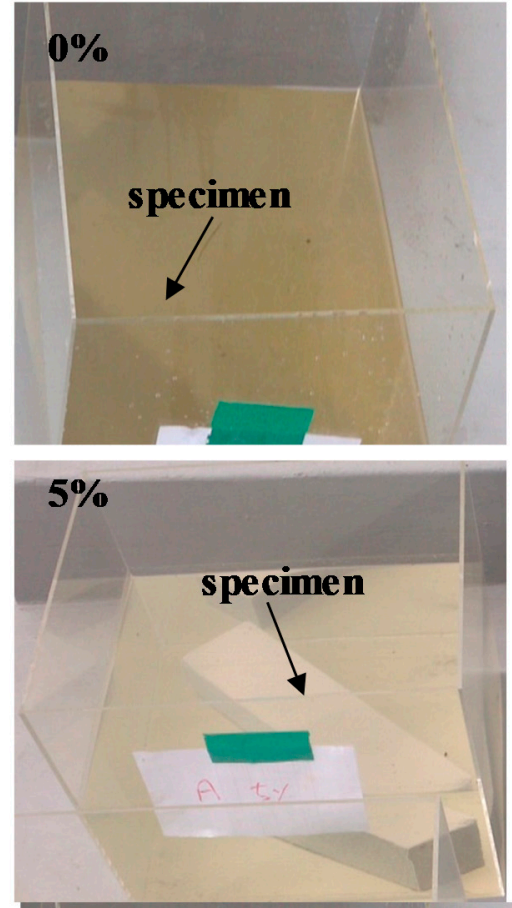

(b)
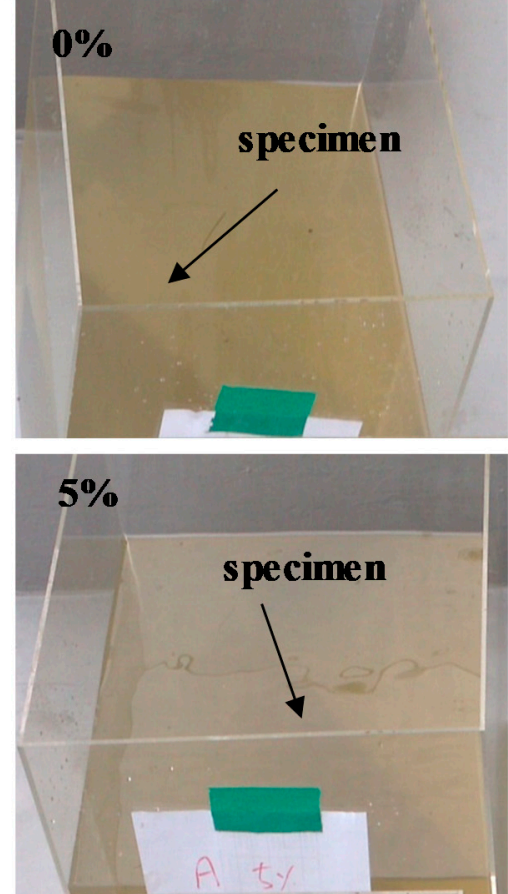

\section{$3 \%$}

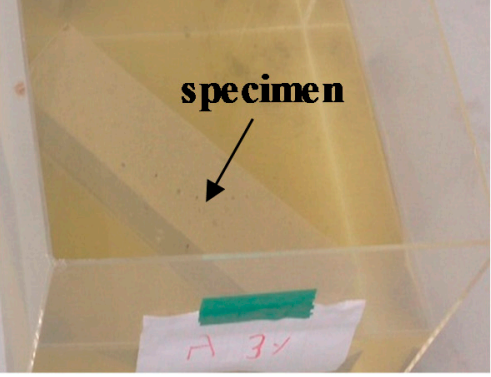

$10 \%$ specimen

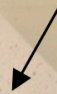

$3 \%$

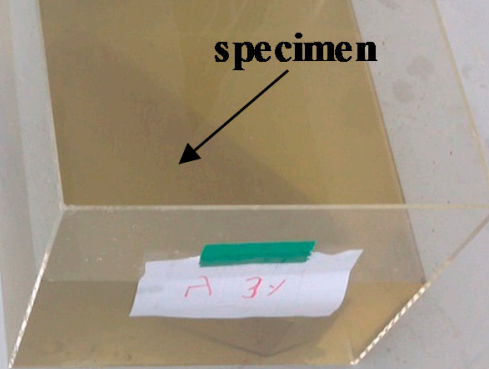

$10 \%$

specimen

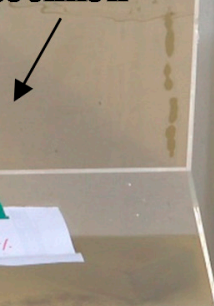

Figure 8. Cont. 
(c)
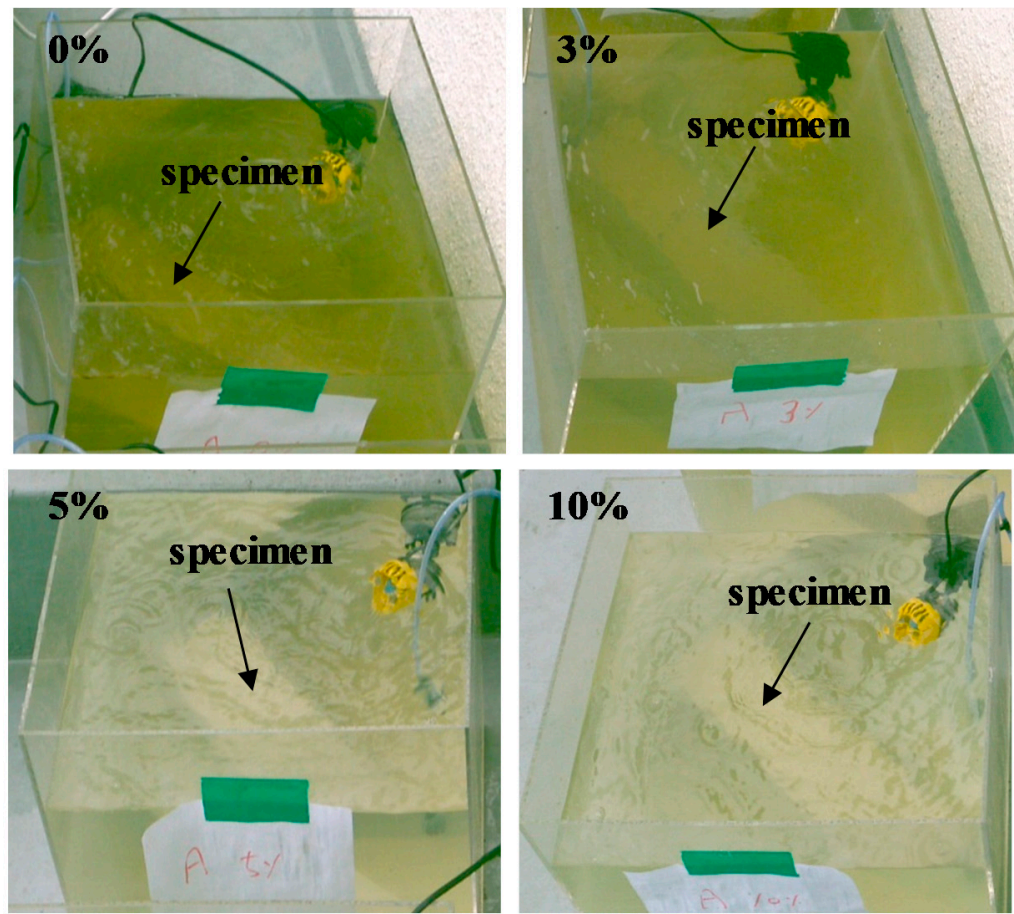

Figure 8. Change in color of $0 \%, 3 \%, 5 \%$, and $10 \%$ L-arginine cement mortar immersed in sea water after (a) 3 days, (b) 7 days, and (c) 14 days.

\subsubsection{Total Dissolved Nitrogen in Distilled Water}

L-arginine can leach out in water from cement mortar; therefore, it is of utmost importance to determine the content of nitrogen with immersion duration. Figure 9 shows the results of dissolved nitrogen in distilled water with L-arginine replacement. From this figure, it can be seen that, as the amount of L-arginine in the cement mortar increased, the total dissolved nitrogen also increased in distilled water with different immersion periods. This result correlates with the recovery of L-arginine in distilled water (Figure 5). It can be inferred from Figure 9 that the amount of dissolved nitrogen is not increased significantly after 28 days of immersion. This result can be correlated with the change in $\mathrm{pH}$ (Figure 7a) of distilled water, where after 14 days of immersion, there was no significant change in value. Up to seven days of immersion, the $\mathrm{pH}$ increased gradually due to leaching of nitrogen. Therefore, regardless of the L-arginine replacement ratio, maximum L-arginine was leached within 28 days of immersion. There was no dissolved nitrogen found in $0 \% \mathrm{~L}$-arginine cement mortar owing to the absence of L-arginine.

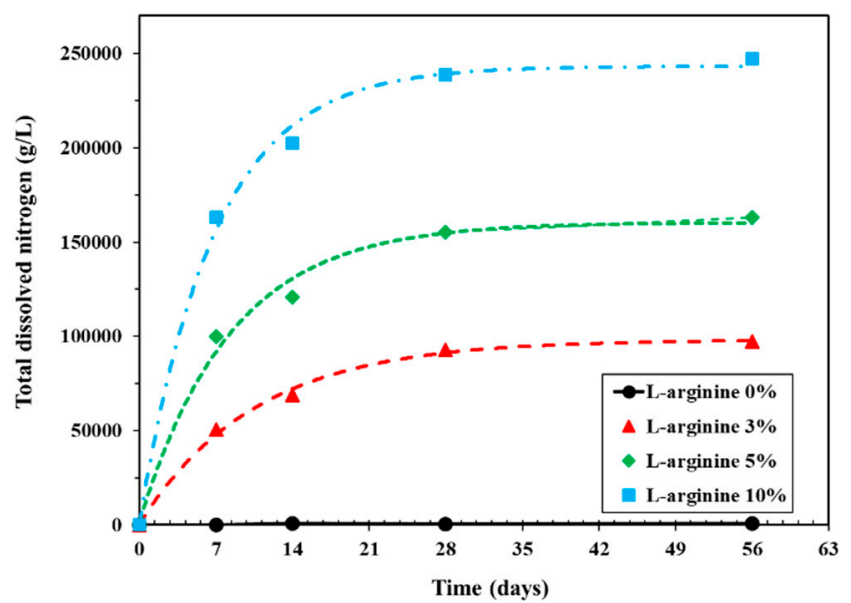

Figure 9. Total dissolved nitrogen of L-arginine cement mortar in distilled water according to immersion duration. 


\subsubsection{Growth of Chlorophyll-A on Mortar Surface}

In order to examine the effect of L-arginine cement mortars on growth of chlorophyll-a, the cement mortar specimens were immersed in the natural sea near the tide embankment located at Ansan city, South Korea. The amount of Chl-a on the cement mortar surface was measured for up to 56 days of exposure. Figure 10 shows the digital image taken during removal of $\mathrm{Chl}$-a from the surface of the cement mortar. Figure 10a,b shows the digital images of Chl-a removed on filter paper after 7 and 28 days of immersion in sea water, respectively. It can be seen that, as the amount of L-arginine increased, the color became gray with the exposure period. The $10 \% \mathrm{~L}$-arginine specimen shows deep gray color (specimen dipped in sea water where Chl-a was attached on the surface), whereas the $0 \%$ specimen, i.e., that without L-arginine, exhibited a light yellow color owing to the scarcity of nitrogen; thus, Chl-a floats in water rather than being deposited onto the cement mortar after 28 days of immersion. This result suggests that, as the amounts of L-arginine and immersion duration are increased, the formation of Chl-a on the surface of the cement mortar specimen is increased.

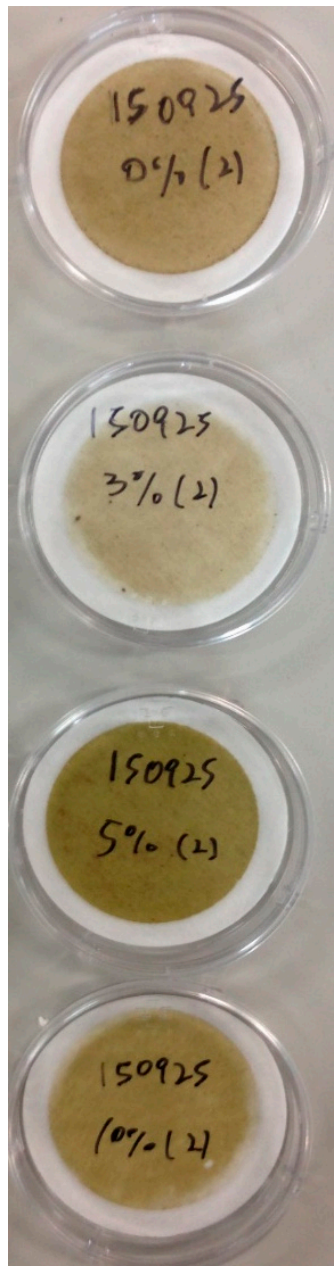

(a)

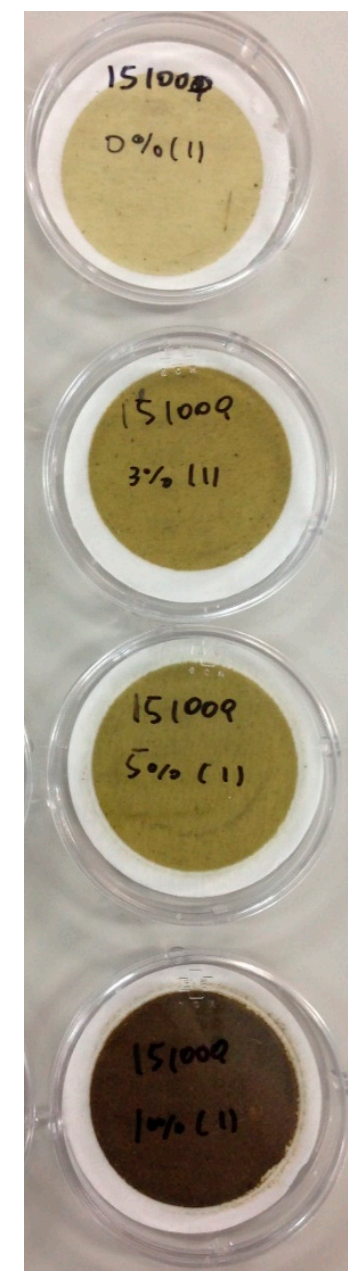

(b)

Figure 10. Digital image of removed chlorophyll-a (Chl-a) on filter paper from the surface of L-arginine cement mortar after (a) 7 days and (b) 28 days of immersion in a sea.

Figure 11 shows the amount of Chl-a extracted from the surface of L-arginine cement mortar according to immersion duration. The amount of Chl-a extracted from $0 \%, 3 \%, 5 \%$, and $10 \% \mathrm{~L}$-arginine cement mortars surface after seven days of immersion in sea water was found to be $0.47,0.53,1.25$, and $1.58 \mu \mathrm{g} / \mathrm{cm}^{2}$, respectively. It can be observed in Figure 11 that, as the amount of L-arginine increased in cement mortar, the amount of Chl-a increased with immersion duration, which correlates 
with the visual observation (Figure 10), where the 10\% L-arginine specimen shows a deep gray color on the paper. It can be seen after 56 days of immersion that the amount of Chl-a extracted from $0 \%, 3 \%$, $5 \%$, and $10 \% \mathrm{~L}$-arginine cement mortar was found to be $1.15,1.84,3.81$, and $4.82 \mu \mathrm{g} / \mathrm{cm}^{2}$, respectively.

Figure 12 shows the Chl-a growth rate on the L-arginine cement mortars versus the mortar without L-arginine. This result shows that 3\% L-arginine mortar increases the rate of Chl-a growth by $112 \%$, whereas $5 \%$ and $10 \%$ L-arginine show $226 \%$ and $336 \%$, respectively, after seven days of exposure. It was observed after 14 days of immersion that the rate of Chl-a slightly decreased.

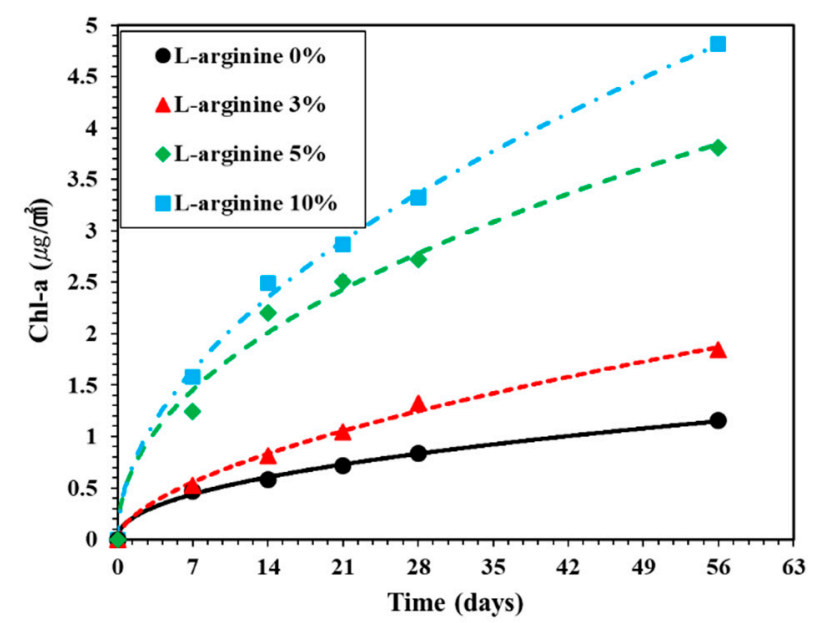

Figure 11. Surface chlorophyll-a content on the surface of L-arginine cement mortar according to exposure periods in the sea.

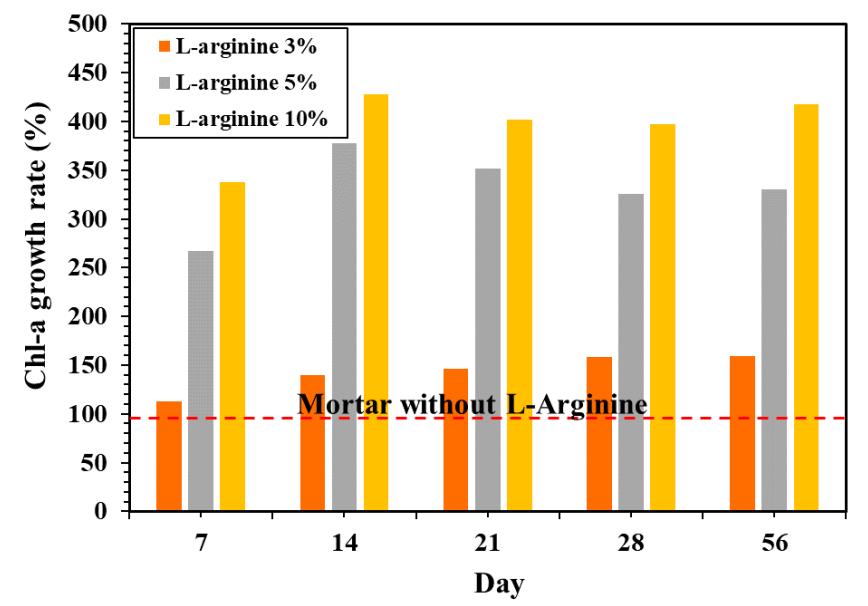

Figure 12. Chl-a growth rate on the surface of L-arginine cement mortar according to exposure periods in the sea.

\section{Conclusions}

Since L-arginine is water soluble, it can easily mix with cement and sand to make cement mortar. Therefore, flow and air content are higher once the L-arginine amount is increased in cement mortar, which leads to a decrease in compressive strength. L-arginine in cement mortar is mostly soluble in a pore solution, which can easily leach out from cement mortar. Thus, the $\mathrm{pH}$ is increased for up to seven days of exposure in distilled water. As the amount of L-arginine is increased in a cement mortar, the amount of dissolved nitrogen increases, which encourages the deposition of Chl-a onto the cement mortar surface. The amount of Chl-a formed on $10 \% \mathrm{~L}$-arginine cement mortar was found to be $4.82 \mu \mathrm{g} / \mathrm{cm}^{2}$, which was highest among all specimens after 56 days of immersion in natural sea. This showed a growth rate of Chl-a 4.2 times higher than that found with $0 \% \mathrm{~L}$-arginine cement 
mortar. Therefore, this process can be recommended for artificial reefs. In addition, the optimum performance can be achieved by controlling the surface roughness, area, and porosity of the cement mortar or concrete.

Author Contributions: Data curation, H.-M.Y.; Formal analysis, H.-M.Y., N.V.M., and J.K.S.; Funding acquisition, H.-S.L.; Investigation, H.-M.Y.; Methodology, H.-M.Y., H.-S.L., and J.K.S.; Supervision, H.-S.L. and J.K.S.; Writing-original draft, H.-M.Y., N.V.M., H.-S.L., and J.K.S.; Writing-review and editing, H.-M.Y., N.V.M., H.-S.L., and J.K.S. All authors have read and agreed to the published version of the manuscript.

Funding: This research received no external funding.

Acknowledgments: This research was supported by a basic science research program through the National Research Foundation (NRF) of Korea, funded by the Ministry of Science, ICT, and Future Planning (No. 2015R1A5A1037548).

Conflicts of Interest: The authors declare no conflict of interest.

\section{References}

1. Firth, L.B.; Knights, A.M.; Thompson, R.C.; Mieszkowska, N.; Bridger, D.; Evans, A.J.; Moore, P.J.; O'Connor, N.E.; Sheehan, E.V.; Hawkins, S.J. Ocean sprawl: Challenges and opportunities for biodiversity management in a changing world. Oceanogr. Mar. Biol. Annu. Rev. 2016, 54, 193-269.

2. Aguilera, M.A.; Broitman, B.R.; Thiel, M. Spatial variability in community composition on granite breakwater versus natural rocky shores: Lack of microhabitats suppresses intertidal biodiversity. Mar. Pollut. Bull. 2014, 87, 257-268. [CrossRef] [PubMed]

3. Chapman, M.G.; Bulleri, F. Intertidal seawalls-new features of landscape in intertidal environments. Landsc. Urban Plann. 2003, 62, 159-172. [CrossRef]

4. Chapman, M.G. Paucity of mobile species on constructed seawalls: Effects of urbanization on biodiversity. Mar. Ecol. Prog. Ser. 2003, 264, 21-29. [CrossRef]

5. Firth, L.B.; Thompson, R.C.; White, F.J.; Schofield, M.; Skov, M.W.; Hoggart, S.P.G.; Jackson, J.; Knights, A.M.; Hawkins, S.J. The importance of water-retaining features for biodiversity on artificial intertidal coastal defence structures. Divers. Distrib. 2013, 19, 1275-1283. [CrossRef]

6. Moschella, P.S.; Abbiati, M.; Åberg, P.; Airoldi, L.; Anderson, J.M.; Bacchiocchi, F.; Bulleri, F.; Dinesen, G.E.; Frost, M.; Gacia, E.; et al. Low-crested coastaldefence structures as artificial habitats for marine life: Using ecological criteria in design. Coast. Eng. 2005, 52, 1053-1071. [CrossRef]

7. McManus, R.S.; Archibald, N.; Comber, S.; Knights, A.M.; Thompson, R.C.; Firth, L.B. Partial replacement of cement for waste aggregates in concrete coastal and marine infrastructure: A foundation for ecological enhancement? Ecol. Eng. 2018, 120, 655-667. [CrossRef]

8. Müllauer, W.; Beddoe, R.E.; Heinz, D. Leaching behavior of major trace elements from concrete: Effect of fly ash and GGBS. Cem. Concr. Compos. 2015, 58, 129-139. [CrossRef]

9. Warati, G.K.; Darwish, M.M.; Feyessa, F.F.; Ghebrab, T. Suitability of scoria as fine aggregate and its effect on the properties of concrete. Sustainability 2019, 11, 4647. [CrossRef]

10. Amin, M.N.; Murtaza, T.; Shahzada, K.; Khan, K.; Adil, M. Pozzolanic potential and mechanical performance of wheat straw ash incorporated sustainable concrete. Sustainability 2019, 11, 519. [CrossRef]

11. Ekström, T. Leaching of concrete: Experiments and modeling. In Division Building Materials; University of Lund: Lund, Sweden, 2001.

12. Gaitero, J.J.; Campillo, I.; Guerrero, A. Reduction of the calcium leaching rate of cement paste by addition of silica nanoparticles. Cem. Concr. Res. 2008, 38, 1112-1118. [CrossRef]

13. Ertelt, M.J.; Raith, M.; Eisinger, J.; Grosse, C.U.; Lieleg, O. Bacterial additives improve the water resistance of mortar. ACS Sustain. Chem. Eng. 2020. [CrossRef]

14. Nosouhian, F.; Mostofinejad, D.; Hasheminejad, H. Concrete durability improvement in a sulfate environment using bacteria. J. Mater. Civ. Eng. 2016, 28. [CrossRef]

15. Al-Salloum, Y.; Abbas, H.; Sheikh, Q.I.; Hadi, S.; Alsayed, S.; Almusallam, T. Effect of some biotic factors on microbially-induced calcite precipitation in cement mortar. Saudi J. Biol. Sci. 2017, 24, 286-294. [CrossRef] [PubMed] 
16. Achal, V.; Pan, X.; Özyurt, N. Improved strength and durability of fly ash-amended concrete by microbial calcite precipitation. Ecol. Eng. 2011, 37, 554-559. [CrossRef]

17. Rose, W.C. The nutritional significance of the amino acids. Physiol. Rev. 1938, 18, 109-136. [CrossRef]

18. Górska-Warsewicz, H.; Laskowski, W.; Kulykovets, O.; Kudli 'nska-Chylak, A.; Czeczotko, M.; Rejman, K. Food products as sources of protein and amino acids-the case of Poland. Nutrients 2018, 10, 1977. [CrossRef]

19. Chen, Q.-F.; Huang, X.-Y.; Li, H.-Y.; Yang, L.-J.; Cui, Y.-S. Recent progress in perennial buckwheat development. Sustainability 2018, 10, 536. [CrossRef]

20. Schier, H.E.; Eliot, K.A.; Herron, S.A.; Landfried, L.K.; Migicovsky, Z.; Rubin, M.J.; Miller, A.J. Comparative analysis of perennial and annual phaseolus seed nutrient concentrations. Sustainability 2019, 11, 2787. [CrossRef]

21. Khaled, K.F.; Al-Mhyawi, S.R. Electrochemical and density function theory investigations of l-arginine as corrosion inhibitor for steel in 3.5\% NaCl. Int. J. Electrochem. Sci. 2013, 8, 4055-4072.

22. Gowri, S.; Sathiyabama, J.; Rajendran, S. Corrosion inhibition effect of carbon steel in sea water by 1-arginine-Zn ${ }^{2+}$ system. Int. J. Chem. Eng. 2014, 2014, 1-9. [CrossRef]

23. Ootsuki, N.; Hirayama, S.; Miyazato, S.; Yokozeki, Y. Fundamental study on estimating of Ca leaching from mortar and the deterioration of mortar. J. Constr. Manag. Eng. JSCE 1999, 634, 293-302.

24. Haga, K.; Toyohara, M.; Sutou, S.; Kaneko, M.; Kobayahi, Y.; Kozawa, T. Alteration of cement hydrate by dissolution, (I)alteration test of hydrate cement paste by water-permeation using centrifugal force. Trans. At. Energy Soc. Jpn. 2002, 1, 20-29. [CrossRef]

25. Hartwich, P.; Vollpracht, A. Influence of leachate composition on the leaching behaviour of concrete. Cem. Concr. Res. 2017, 100, 423-434. [CrossRef]

26. Sun, Z.; Vollpracht, A.; Sloot, H.A. pH dependent leaching characterization of major and trace elements from fly ash and metakaolin geopolymers. Cem. Concr. Res. 2019, 125, 1-14. [CrossRef]

27. ASTM C150. Standard Specification for Portland Cement; ASTM International: West Conshohocken, PA, USA, 2019.

28. ASTM C33. Standard Specification for Concrete Aggregates; ASTM International: West Conshohocken, PA, USA, 2018.

29. ASTM C1437. Standard Test Method for Flow of Hydraulic Cement Mortar; ASTM International: West Conshohocken, PA, USA, 2013.

30. ASTM C230. Standard Specification for Flow Table for Use in Tests of Hydraulic Cement; ASTM International: West Conshohocken, PA, USA, 2014.

31. ASTM C185. Standard Test Method for Air Content of Hydraulic Cement Mortar; ASTM International: West Conshohocken, PA, USA, 2015.

32. ASTM C109. Standard Test Method for Compressive Strength of Hydraulic Cement Mortars; ASTM International: West Conshohocken, PA, USA, 2016.

33. Rowell, D.L.; Vo-Dinh, T.; Gauglitz, G. Chemical and Biological Sensing Technologies Ii, Soil Science: Methods and Applications, Soil Acidity and Alkalinity; Longman Scientific and Technical: Harlow, UK, 1996; Volume 3, pp. 153-174.

34. ASTM D4972-13. Standard Test Method for $\mathrm{pH}$ of Soils; ASTM International: West Conshohocken, PA, USA, 2013.

35. Behnood, A.; Tittelboom, K.V.; Belie, N.D. Methods for measuring pH in concrete: A review. Constr. Build. Mater. 2016, 105, 176-188. [CrossRef]

36. ASTM D8083. Standard Test Method for Total Nitrogen, and Total Kjeldahl Nitrogen (TKN) by Calculation in Water by High Temperature Catalytic Combustion and Chemiluminescence Detection; ASTM International: West Conshohocken, PA, USA, 2016.

37. ASTM D3731. Standard Practices for Measurement of Chlorophyll Content of Algae in Surface Waters; ASTM International: West Conshohocken, PA, USA, 1987.

38. Jeffrey, S.W.; Humphrey, G.F. New spectrophotometric equations for determining chlorophylls a, b, c1 and c2 in higher plants, algae and natural phytoplankton. Biochem. Physiol. Pflanz. 1975, 167, 191-194. [CrossRef]

39. Behbahani, A.E.; Soltanzadeh, F.; Jomeh, M.E.; Zadeh, Z.S. Sustainable approaches for developing concrete and mortar using waste seashell. Eur. J. Environ. Civ. Eng. 2019. [CrossRef]

40. Hellier, M.D.; Thirumalai, C.; Holdsworth, C.D. The effect of amino acids and dipeptides on sodium and water absorption in man. Gut 1973, 14, 41-45. [CrossRef]

41. Wapnir, R.A.; Wingertzahn, M.A.; Teichberg, S. L-arginine in low concentration improves rat intestinal water and sodium absorption from oral rehydration solutions. Gut 1997, 40, 602-607. [CrossRef] 
42. Bordes, R.; Holmberg, K. Amino acid-based surfactants-do they deserve more attention? Adv. Colloid Interface Sci. 2015, 222, 79-91. [CrossRef] [PubMed]

43. Negim, E.S.; Kozhamzharova, L.; Khatib, J.; Bekbayeva, L.; Williams, C. Effects of surfactants on the properties of mortar containing styrene/methacrylate superplasticizer. Sci. World J. 2014, 10. [CrossRef] [PubMed]

44. Sylvie, C.-A.; Isabelle, C. Foams: Structure and Dynamics; Cantat, I., Cohen-Addad, S., Elias, F., Graner, F., Hhler, R., Pitois, O., Rouyer, F., Saint-Jalmes, A., Cox, S., Eds.; Oxford University Press: Walton Street, UK, 2013.

45. Du, L.; Folliard, K. Mechanisms of air-entrainment in concrete. Cem. Concr. Res. 2005, 351, 463-1471. [CrossRef]

46. Shah, S.P.; Choi, S.; Janse, D.C. Strain softening of concrete in compression. Proc. Fract. Mech. Concr. Struct. 1996, 3, 1827-1841.

47. Zheng, X.; Ji, T.; Easa, S.M.; Ye, Y. Evaluating feasibility of using sea water curing for green artificial reef Concrete. Constr. Build. Mater. 2018, 187, 545-552. [CrossRef]

48. Chen, C.; Ji, T.; Zhuang, Y.; Lin, X. Workability, mechanical properties and affinity of artificial reef concrete. Constr. Build. Mater. 2015, 98, 227-236. [CrossRef]

49. Jones, M.R.; Macphee, D.E.; Chudek, J.A.; Hunter, G.; Lannergrand, R. Studies using 27 Al MAS NMR of AFm and AFt phases and the formation of Friedel's salt. Cem. Concr. Res. 2003, 33, 177-182. [CrossRef]

50. Suryavanshi, A.J.; Scantlebury, J.D.; Lyon, S.B. Mechanism of Friedel's salt formation in cements rich in tri-calcium aluminate. Cem. Concr. Res. 1996, 26, 717-727. [CrossRef]

51. Yang, Y.; Ji, T.; Lin, X.; Chen, C.; Yang, Z. Biogenic sulfuric acid corrosion resistance of new artificial reef concrete. Constr. Build. Mater. 2018, 158, 33-41. [CrossRef]

52. Ramesh, K.G.B.; Kesavan, V. A review analysis of cement concrete strength using sea water. Mater. Today Proc. 2020, 22, 983-986. [CrossRef]

53. Sagi, A.A.; Moreno, E.I.; Andrade, C. Evolution of pH during in-situ leaching in small concrete cavities. Cem. Concr. Res. 1997, 27, 1747-1759.

(C) 2020 by the authors. Licensee MDPI, Basel, Switzerland. This article is an open access article distributed under the terms and conditions of the Creative Commons Attribution (CC BY) license (http://creativecommons.org/licenses/by/4.0/). 